\title{
"The Alliance is not our whole Foreign Policy": Salazar's Speeches and Notes about the Anglo-Portuguese Alliance and the Attitude of the Portuguese Government towards Britain during the Spanish Civil War [September 1936-July 1937]
}

\section{Introduction}

$\mathrm{n}$ an attempt to stem the escalation of the Spanish Civil War to other countries, France and Britain proposed, shortly after the pronunciamiento on 17-18 July 1936, the signing of a non-intervention agreement with other nations, including Germany, Italy, Portugal, and the Soviet Union, all of which had definite stakes in the outcome of the conflict. The signatories should renounce the traffic of materiel and the recruitment of volunteers. Nevertheless, the terms of the Agreement spelled the international isolation of the Republic, while turning a blind eye to the flow of war material and troops from Italy and Germany to the nationalist faction from the very outset, and later to Soviet support to the Republican cause. (Thomas, 1961: 226) As early as 25 July Count Ciano, the Italian Minister of Foreign Affairs, received Antonio Goicoechea and Pedro Sainz Rodriguez and on that very same day Mussolini would agree to sending airplanes to Morocco. The next day, Hitler gave his assent to support the insurgents and the first German men and materiel arrived in Cádiz on 5 August. The Soviets would only intervene by the end of October 1936. Compared with these countries, Portugal's involvement was markedly more discreet, but by no means less critical. 


\section{REAP/JAPS 26}

\section{As Hugh Thomas sums up:}

It was through Portugal that the greater part of German aid was first sent. The part of that country in the Spanish Civil War was simple. Less clerical than the Portuguese corporative regime, the Spanish Nationalists stood for almost the same things as "gracious Salazar" as the South African poet Roy Campbell caller him. The military aid which Salazar could give the Nationalists was small. But he gave them many other things as valuable: a place in which to plot; a refuge; a means of communicating between their two zones at the start of the Civil War. Nicolás Franco, the general's eldest brother, with Gil Robles, was permitted to establish his headquarters for the purchase of arms at Lisbon. The Republican Ambassador in that capital, Sánchez Albornoz, swiftly became a prisoner in his own Embassy. Salazar remarked on August 1 that he proposed to help the rebels "with all available means" - including the intervention of the Portuguese army, if this should be necessary. As a result, Spanish Republicans who escaped into Portuguese territory were usually handed over to the Nationalists. The Portuguese Press served the Nationalists from the start. On August 20, the German Minister at Lisbon reported that war material brought from Germany in the steamships Wigbert and Kamerun had been despatched onwards to Spain most smoothly. Salazar, he said, had removed "all difficulties (...) by his personal initiative and handling of details." (Thomas, 1961: 231)

Taking into account this picture of Portugal's role in the war and the circumstances in which Salazar tried to stay ahead of the game, this study serves two objectives. The first one is to understand the ways in which Salazar assessed the role of Britain in the Non-Intervention Committee (NIC) from September 1936 to July 1937, notably through his Notes and Speeches, originally published in Coimbra in 1937. The second objective, still based on the same documents, is to examine how he depicted the Anglo-Portuguese relations and the Alliance in the first year of the Spanish Civil War. It should be noted that this period marks the transition from a position of professed neutrality and impartiality (though only in appearance) to a position where he openly champions the nationalist cause in Spain as the only way to stop the progress of communism in Europe. The tipping point was the attempt on his life on 4 July 1937. There he 
claims that he does not fear the hatred that his critics in Britain bare him and that Portugal, though still cherishing the Alliance, must be able to steer its own course and live up to its political principles, even if that meant opposing the British public opinion.

The period until July 1937 was also a critical time for the Non-Intervention Committee (NIC). From May 1937 on it witnessed some important changes, with the withdrawal of Italy and Germany, and with the arrival of Neville Chamberlain in Downing Street to replace Stanley Baldwin as Prime Minister of the National Government. Both Chamberlain and Anthony Eden, the Foreign Secretary, were more interested in a victory of the fascist forces. Chamberlain, a stern advocate of Britain's appeasement policy, abstained from antagonising Mussolini. Eden apparently had no qualms about telling Yvon Delbos, the French Foreign Minister, that he hoped to see the Nationalists win the war - although Hugh Thomas rushes to defend Eden, arguing that it had been "a hasty aside by Eden", given the fact that all evidence pointed to Eden's perplexity as to whom he should champion. (Thomas, 1961: 467)

The collection of António de Oliveira Salazar's Speeches and Political Notes from 1928 to 1966 was recently republished. (Salazar, 2016) The texts under analysis had been first published in 1937, as part of the second volume (Salazar, 1937), but it did not include two notes, namely nos. XXIV (on the participation of foreign volunteers) and XXV (on an inquiry into the bombing of Guernica), now made public for the first time.

From the start of the conflict, Portugal, despite its claims of impartiality and fair treatment of the warrying forces, knew all too well whose side it should support. It accepted the Non-Intervention Agreement on 13 August 1936 - hardly a week since France had unilaterally declared its policy of non-intervention -, but did not haste to join the NIC, which only happened in its third meeting, on 28 September. ${ }^{1}$

The skilfully embroidered academic language that characterises Salazar's discourse barely hides, behind his wordy formulations, where his political sympathies lay. This blend of scholarship and ideology was aptly labelled by the Spanish philosopher Miguel de

1. The first meeting was held on 9 September and the second on 14 . 
Unamuno. In an article written in 1935 for the Ahora newspaper, the then Dean of the University of Salamanca made reference to Salazar's regime as a "Fascismo de Cátedra" ("Academic Fascism", ${ }^{2}$ which was a combination of the political role of three elites: the academic; the military; and the clerical). (Torgal, 2009a: 295; 2009b: 8)

On closer examination, as one reads his notes and speeches, one is going to find a continuous reversal of roles, blatant contradictions, the manipulation of arguments to distort the truth and claims refuted by factual evidence gathered by foreign correspondents on the ground. He invokes history, tradition, and the character of the Portuguese people to stake his claims to how values such as humanity, peace, sense of justice and defence of civilization actually shape the policies of his Government towards the civil war next door. In his Portugal Now (1937), Ralph Fox had denounced this duplicity through the metaphorical appropriation of Eça de Queirós's own words inscribed on the pedestal of his monument, and which he translated in the following way: "over the hard and naked truth he flung a delicate veil of fantasy". (Fox, 1937: 21) To which he added: "It is a perfect symbol of modern Portugal, and the ironist of history has decreed that the corporative state's propaganda chief should also be called Eça de Queiros". ${ }^{3}$

Salazar had reasons to be exasperated by the opinions aired in Britain against his regime. Reports on the unloading of war material in Lisbon intended for the insurgents came out in British and French newspapers even before Portugal's note of adhesion was published. Pressure on the part of the labour movement was put on the National Government as early as 26 August 1936. A deputation led by Walter Citrine (the TUC General Secretary) and Arthur Greenwood

2. Translation by Luís de Reis Torgal, "Salazar and the Portuguese 'New State' - Images and Interpretations". Annual of Social History, 2 (2009): 8. All the remaining translations from Portuguese into English were made by me.

3. Little did Fox know that António Eça de Queirós was in fact the son of the novelist. He had joined he national-syndicalist movement in June 1933 and was entrusted with the supervision of the nationalist students' movement "Acção Escolar de Vanguarda." He was also the chief editor of the Jornal do Comércio e das Colónias, on whose pages he defended the role of the Propaganda Agency and the need to "educate, create, strengthen and spread the colonial sentiment in the Portuguese spirit and soul". (Queirós, 1933. My translation) He was later appointed sub-director of the Secretariat for National Propaganda (1943) and President of the Board of the Emissora Nacional de Radiodifusão (1951-1959). See also Garcia, 2011: 134, 137 and Kuin, 1993: 560-1. 
(deputy leader of the Labour Party) met with Eden and Lord Halifax on 26 August. As they stated, "unless Portugal could be got to come into the agreement at once and put it into strict force, the whole object of the non-supply of arms policy would be defeated." However, during that meeting it became apparent that the Government had already set its policy regarding Salazar, a policy that was to remain consistent, despite some attrition, until the end of the conflict. The Foreign Secretary stressed "the unique and difficult position in which Portugal is placed, both geographically and politically vis-àvis the present troubles in Spain", before reassuring his interlocutors that "everything is being done and has been done to exert pressure from here on the Portuguese Government with a view to bringing them into the proposed agreement". (Apud Stone, 1994: 21) Despite this early assurance of the British Government, Portugal remained intransigent, and until the end of the conflict always sought to undercut the fragile power of the NIC in relation to schemes of international supervision, as Salazar would always oppose foreign control on national soil.

XVIII. Note of the Portuguese Government dated 11 December 1936 (Anglo-French Non-Intervention Project and Mediation in the War in Spain) ${ }^{4}$

In the Memorandum of 5 December 1936, Britain and France invite Germany, Italy, Russia and Portugal:

- To declare their decision to renounce to any direct or indirect action leading to foreign intervention in the war in Spain.

- To adopt measures to inspect all materiel headed for Spain.

- To play a part in the mediation led by Britain and France in the attempt to "allow Spain to express the national will", or "to allow the whole of the country to express its national will".

4. Cf. Salazar, 2016: 277-81. 
Salazar acknowledges that the document is moved by the "most generous intentions": peace, the saving of western civilization and humankind. However, he claims that Portugal is in a privileged position to understand the essence of "the Spanish question" and to draw its own conclusions about the true nature of the Spanish revolutionary movement. Portugal must be able to reconcile the general interests of peace and humanity with its own vital interests, but he immediately argues that the latter cannot be sacrificed, cost whatever it may, for risk of endangering its own existence.

Salazar is well aware that, in practical and political terms, the Non-Intervention Agreement cannot be implemented. He admits that the facts preceding the Agreement had already dictated its own failure. He considers that it was the statements of political leaders in some countries favouring one of the parts that led, "by natural opposition of ideologies", other countries to side with the other part.

Yet, he believes that the Portuguese Government has sought, with utmost correction, to live up to its international commitments and has gone further than many other Governments by abstaining from indirect action. Lisbon, he claims, will not hesitate to pass legislation to enforce the Agreement. This comes with a caveat, though: such legislation is to be based on that of other countries.

In this first note, Salazar voices a critical, if not pessimistic, assessment of the NIC. He claims he will instruct the representative of the Portuguese Government there to express the following objections. On the one hand, the NIC is struggling to cope with the challenges of its mission and that it fails to lend credence to its own attempts to secure peace in the eyes of public opinion; therefore, the NIC should publicly acknowledge such inefficiency. On the other, the NIC, within its remit, should look into immediate measures to carry out an effective inspection, as originally agreed; however, such measures can only be implemented and enforced by individual Governments. And yet, Governments are deprived of freedom of action in this matter due to domestic political pressures and the mounting attacks on the international order deriving from the manipulation of the masses on the part of some Governments. This fosters fake impartiality and gravely impairs justice.

When it comes to the inspection of arms trafficking, Salazar argues that Portugal does not manufacture weapons and that, given 
the threat of international communism, cannot afford to furnish them to a third party. Regardless what the NIC may agree on this matter, Portugal must remain in full control of the inspection process: only its national laws are valid for the purpose, not a set of rules imposed from outside. Still, Portugal will not shy away from the moral obligation to seek to alleviate the painful conditions in Spain, and to attempt mediation between the conflicting parties, as called for by the British and French Governments. Salazar stresses that Portuguese history and tradition have shown its commitment to the principle of humanity, as demonstrated by the inexistence of death penalty in its Penal Code. However, it will not confuse this humanitarian commitment with feebleness and lack of moral conviction to act against those who are willing to inflict pain on an entire people. The inability to perceive this has led to a misleading perception of the Spanish conflict, which, in turn, dooms to failure any plans that may be devised to address the problem.

The priority, he claims, is to ease the pain of the Spanish population, regardless of their political alignment. And for that Portugal has provided humanitarian aid across the border, but since the nationalist forces are in control of all the territory adjacent to the border, it is only natural that such aid is handed over to the nationalist authorities.

The Portuguese Government does not recognise the Government of Valencia, but it has "not yet" recognised the Government of Burgos either (which means it will soon).

Salazar also claims that the Portuguese Government recognises the need for food and medicine to be supplied to the civilian population, the right of asylum to be granted to those who applying for it, the prisoners to be treated with humanity and in accordance with the law, and assistance to be provided to non-combatants. Above all, to protect the vanquished, help in the reconstruction of Spain and guarantee that the victorious Government is unanimously acclaimed as that of all Spaniards.

Mediation, however commendable, is based, so Salazar claims, on false premises: that the Spanish plight boils down to an armed conflict between two political parties; that all they are trying to do is seize power; and that it is possible to reach an agreement by means of a general election. He, nevertheless, believes that what is at stake in Spain is something far more dramatic and troubling, namely a "clash 
between two civilizations or the clash between civilization and barbarism". Mediation is therefore doomed to failure. And here another contradiction in regards to his professed impartiality and desire for peace: it is preferable to let one of the contending parties win and form "a strong but generous Government", than to let the conflict go on scourging the country with serious implications for western civilization. More important than war, he claims, is peace, but that peace comes with a price, and the price is to chastise those who advocate terror to push their ideological and political agenda. It goes without saying that he is not referring to Franco and his generals.

\section{Note of the Portuguese Government dated 2 January 1937 [Recruitment of Volunteers for the War in Spain] ${ }^{5}$}

This note is a reaction to the memorandum sent by the British Government on 28 December 1936, which declared that the most urgent problem to tackle in the Spanish war was the volunteers. In a memorandum sent to the British and French Governments on 21 August 1936, Portugal had already made it clear that it would walk out of the Agreement if, in any of the signatory countries, the recruitment of volunteers to the war front or public subscriptions for military purposes ever took place. Salazar feels he holds the moral high ground, for he claims that such a thing does not happen in his country, all the more so because, traditionally, the Portuguese usually abstain from taking part in the political struggles of the neighbouring country. Salazar is convinced that the number of Portuguese fighting in the Spanish Civil War is negligible, and even those can hardly be considered true patriots, as most are communists who fled the country before the war broke and have been conspiring "against Portugal" before joining the ranks of the republican militias. Salazar, nevertheless, seeks to locate the clash of ideologies as something occurring predominantly outside Portugal's borders. This clash has made the fight in Spain "inevitable" and has caused the disruption

5. Idem: $283-4$. 
of the international order. If no measures are taken to isolate it, so he argues, other countries can be dragged into the conflict. Consequently, the Portuguese Government sees no impediment to the imposition of legal restrictions to the recruitment of volunteers, although they realize that this is alone will not suffice, for fear it may give way to other forms of support. Again, Salazar pretends to uphold the principle of impartiality: countries should avoid backing one part or the other so that neither can benefit from conditions that are more advantageous. However, he knows that this concern of his can be easily belied, and that is why he spares no words in his attacks on the NIC for not fulfilling its duty to fend off unsubstantiated accusations made against some of the signatories. And what is worse is that two of the countries, Britain and France - though he does not name them -, stirred up by the press, should feel emboldened to recommend measures to the other countries that have not even been heard, in total disregard of the aims and functions of the NIC. According to Salazar, this undermines the credibility and purpose of the committee. Defending this or that course of action towards the Spanish conflict, in spite of the best of intentions, is regarded as a threat to the confidence the countries should place in the NIC. One cannot expect the NIC to serve the cause of Non-Intervention and to observe its deliberations while the political leaders of some of the signatories to express their views about the way in which Spain and all the other countries should conduct themselves. Still, Portugal is willing to honour the spirit of the original agreement and to pass legislation against the recruitment of volunteers in its territory, provided the other countries also agree to do it. However, the Portuguese Government will not give the first step: the Portuguese Bill will be based on that of the other countries. 


\section{Note of the Portuguese Government dated 12 January 1937 [English Proposal concerning the Volunteers for the War in Spain] ${ }^{\circ}$}

This very same position would be reiterated ten days later, after Portugal received a memorandum from His Majesty's Government on 11 January. Salazar acknowledges the gravity of the situation in Spain, as mentioned in the document, and claims that, in terms of adopting restrictive measures to prevent the enlisting of volunteers, the country will not hesitate to follow suit, as the Portuguese Constitution allows the Government to promulgate such laws without further delay. For that to happen, however, Salazar sets two conditions: that all countries agree on a common date of entry into force of that measure; and that the restrictions are to be applied not only to the nationals of each country, but also to all non-national residents or foreigners in transit to Spain. This reply, Salazar insists, does not mean that by seeking to address the issue of the volunteers, as requested by the British Government, other direct or indirect forms of interference in the conflict are now less important in the eyes of the Portuguese Government. As for the inspection measures, Salazar sees no reason to worry, as the British memorandum reminds its addressees that it should be up to each signatory to fulfil the commitments that had been previously undertaken, and in this respect Portugal has nothing to add. It would take four more months before the Non-Intervention Committee scheme to patrol ports and frontiers came into effect on 19 April.

6. Idem: 285-6. 
ESTUDOS/ESSAYS

\section{Note of the Portuguese Government dated 20 May 1937 [The Withdrawal of the Foreign Volunteers]}

In reply to the memo drafted by Charles Wingfield, the British ambassador, dated 18 May, in which the Portuguese Government is requested to join other countries in an appeal for cessation of hostilities so that the withdrawal of volunteers from Spain can be effected, Salazar seizes the opportunity to, once again, criticise the NIC and the diplomatic initiatives of the British Government. He sees this move as gravely affecting the prestige of the very committee that was set up with the sole purpose of preventing foreign interference in the Spanish matters, as its members are being outmanoeuvred by political sleights of hand meant to dodge the more difficult task of reaching a unanimous course of action within that international body. On the other hand, Salazar cannot understand how such moratorium could be executed without a carefully thought-out plan to be duly discussed and approved by the Governments and conflicting parties concerned. Salazar, however, voices his suspicion not only of the way in which the NIC is being side-lined and its members prevented from negotiating their political stances, but also of the opportunity of the British proposal, as rumours were already circulating that one of the parties was preparing a major offensive. The adoption of the proposal advanced by the British Government, Salazar argues, would clearly influence the outcome of the war, as it would dictate the military superiority of one of the belligerents. ${ }^{8}$ This alone would ruin all efforts of impartiality, which Salazar deems necessary for the success of any collective initiative acceptable in the eyes of the conflicting parties. In the light of these considerations, therefore, Salazar rejects the British advances laid down in Wingfield's memo.

7. Idem: $297-8$.

8. In fact, the Republican Offensive against Huesca would start a few weeks later, on 12 June, only to be cancelled shortly afterwards, when the nationalist troops captured Bilbao. 


\section{Note of the Portuguese Government dated 21 May 1937 (Inquiry into the Destruction of Guernica)}

On 26 April, Guernica was carpet-bombed for over three hours, levelling most of its buildings and resulting in a massive number of civilian casualties. Operation Rügen, as it was codenamed, sparked an outcry across the world but Salazar saw no reason why "the Guernica case" should be singled out, when other acts of destruction carried out across the country have not drawn similar international condemnation. Salazar does not seem as concerned about the object of the humanitarian appeals as he is about highlighting the spirit of impartiality as the inspiration behind those appeals. Otherwise, such appeals, so Salazar argues, would merely serve the purpose of reprimanding one of the belligerents. This is all the more suspicious as these humanitarian outcries, so he argues, are only distinctively heard in the press when the military operations of this one particular belligerent result in decisive gains on the ground. Therefore, Salazar does not simply disregard the content of the appeals: he actually claims that humanitarian causes can be made to serve political goals - and when that happens, it desecrates that spirit of impartiality. In fact, Salazar finds it difficult to account for such a sudden interest in Guernica to the point of there being people calling for an international inquiry, all the more so because the town is located in a war zone with a large number of military operations going on there. This alone, he argues, suffices to make Franco refuse to grant permission to such an inquiry, and by doing so, he would meet the expectations of the Basque Government, which would use his refusal to fuel negative speculations about the intentions of the Nationalist forces.

Salazar argues that the attempt to push for an international inquiry is inconsistent with the policy of non-intervention, alleging that since the powers are not taking part in the conflict, they should not be allowed to play the part of judges. What he does not do, however, is to explain how this argument of his conforms to the principles of impartiality and justice. This line of reasoning, taken to

9. Idem: 299-300 
its logical conclusion, makes non-intervention and impartiality coterminous not only with moral indifference, but also with political omission. Salazar concludes that the initiative of the Basques should, therefore, be discarded and that, if an international inquiry is to be conducted, then it should be into all the situations where suffering is inflicted on the civilian population. However, he quashes the plans for the inquiry as he reminds the signatories of the Non-Intervention Agreement that they lack the legal basis to set it up.

\section{Address of Salazar at the National Assembly on 6 July 1937 [Portugal, the English Alliance and the Spanish War) ${ }^{10}$}

The speech delivered at Hall of the Lost Steps of the National Assembly on 6 July 1937, immediately after the attempt on his life (4 July, 1937), where he thanked the officers who succeeded in thwarting it, was focused on the weight the Alliance had in the definition of the Portuguese foreign policy. Whereas in the previous notes Salazar tried to uphold the (albeit ill disguised) principle of absolute neutrality, here he unabashedly lashed out against those who, in Britain and France, raised their voices against the regime's support to the Nationalist forces. By this time, Germany and Italy had already withdrawn from the NIC (on 30 May) and the role of the NIC was greatly curtailed.

In his speech, Salazar seeks to understand the causes that led to attempt, as it does not match the picture that he himself paints of the country. He does not go to great lengths to deny the "fascist" label that has been attached to dictatorship, but draws the line in relation to other countries: Portugal's regime is as "mild as the country's manners, modest like the nation itself, and that values the Portuguese and their work". (2016: 303) Bound together by the higher aspiration of national aggrandisement, so he states, the Portuguese people do not get involved in political agitation nor do they let themselves be torn apart by the hatred of the masses or of class divisions. In other words, nationalism not only suppresses class divisions and keeps the country

10. Idem: 303-8. 
free of tensions, but also gives people a sense of common purpose and strengthens their belief in the existence of a single, unified social body. Thus, the causes of the attempt on his life, he concludes, cannot be domestic, but international. In his eyes, the systems of ideas - "systems of crimes", as he calls them - circulating out there are somehow exogenous to the national temperament, and have been born out of the mental and moral distress that currently plagues Europe.

He does not go as far as claiming that such distress has been caused by one single "supreme leader" in a distant empire, trying to pull the strings of world order and bent on the destruction of western civilization. What exists, instead, is a tacit understanding among the "elements" committed to creating disorder; an understanding that renders their actions more effective, as opposed to the lack of coordination of the advocates of order. These elements are all inspired and united by both a "common sentiment" and a "common intelligence". Therefore, whatever happens inside the national borders is a reflection of supranational ideological or political interests. Here Salazar acts out another role reversal: the insurgents are not fighting against a legitimate Government, they are fighting off the threat to civilization.

This supranational threat prompts Salazar to reflect on how the Anglo-Portuguese Alliance has borne upon Portugal's foreign policy and its position on the European stage. He starts by claiming that it is necessary to clear any doubts and misunderstandings there may be about the Alliance. Despite the criticisms voiced in UK, Salazar knows that England would never be a champion of communism and that he knows he can trust Britain to prevent Portugal from being absorbed into an Iberian Federation of Soviet Republics.

Salazar provides an overview of the evolution of Portuguese policy since the Revolution of 1926 and explains how the myths of economic, financial and political national decadence were dispelled in a period of ten years, to conclude that Portugal is now stronger than ever before. He acknowledges that it has since long been up to the British to come up with the arguments to defend the Alliance. The first author he chooses is an eloquent example of the way he cautiously reminds Britain that it depends as much from Portugal, as Portugal depends from Britain. Salazar quotes Lord Palmerston, who, in a letter addressed to J. Russell on 9 August 1847, reminded his interlocutor that Lisbon occupied a key strategic position of paramount importance for the 
protection of the British naval interests in the Mediterranean. Without Portugal, in the case of a conflict with France and Spain, all ports from Calais to Marseille would be hostile. The actual letter reads:

Those advantages are many, great and obvious: commercial, military and naval, and if we were to lose them, some of them would not be mere loss, but would become formidable weapons of attack against us in the hands of a hostile power. For instance, the naval position of the Tagus ought never to be in the hands of any power (...) which might become hostile to England, and it is only by maintaining Portugal in its separate existence, and in its intimate and protected state of alliance with England, that we can be sure of having the Tagus as a friendly instead of its being a hostile naval station. Only fancy for a moment Portugal forming part of Spain, and Spain led away by France into war with England, and what would be our naval condition with all the ports from Calais to Marseilles hostile to us (...) and with nothing between us and Malta but Gibraltar. (...) If on the contrary the Tagus were at our command, we should occupy an intermediate position greatly impeding the naval movements of France and Spain. (Apud Bourne, 1970: 276)

The then Foreign Secretary knew how vital it was to secure Portugal's independence from powers like France or Spain by means of a close alliance that would enable Britain to keep the two major continental powers in check, but Salazar concedes that circumstances have changed for a period of almost a century. France and Spain no longer pose a threat to Britain, and it enjoys peaceful relations with the United States. However, while other powers have gained greater substantial commercial and military weight, the British Empire has expanded. The trading routes across the South Atlantic, the Mediterranean and around the Cape have to be kept free. In this speech, Salazar reminds his British allies of Portugal's strategic location, including that of its Atlantic Islands and of the overseas colonies, and of how their geography lies at the convergence of the major seaways.

This means that the Portuguese and the British still share common interests. And this commonality of interests, so Salazar claims, puts them on equal footing. This emphasis on the interdependence between the two countries undercuts ideas that may exist of superiority or subservience in the bilateral relations. Therefore, if it is true 
that the British intervened to help Portugal secure its independence in the past, it is no less true that the Portuguese fought alongside the British in crucial moments of their history. Salazar quotes Lord Nelson's recognition of the valour of the Portuguese navy, namely during the Siege of Malta in 1797 against the French Republic, in a letter to the Marquis of Malta, dated 24 October of that year. Later on, in the preparation of the Waterloo campaign, Lord Wellington, reminding himself of the Battle of Buçaco, longed for the presence of Portuguese troops alongside his men.

In periods of national decadence, this interdependence has been forgotten, but Salazar acknowledges it is not Britain's fault. In fact, it is Britain that has reminded Portugal of the need to remain strong and independent, and not to rely entirely on the Alliance. He goes on to quote the then Secretary of State for Foreign Affairs and Home Secretary, Lord Hawkesbury, who, in January 1802, reminded the Portuguese minister in London that it is only natural that the Prince Regent, considering the political circumstances in Europe, should look after his own army and have it commanded by a trustworthy general; that being the case, then Britain could consider providing military assistance. Otherwise, it would be unwise and irresponsible for the British to ship twenty-thousand men or less to a country whose army lacked organisation. One year later, in a memorandum dated 7 June 1803, the British secretary insisted on that same argument, stating that Portugal could not afford to rely entirely on foreign assistance and that the security of the state should depend on its own efforts. This idea plays into Salazar arguments. If Britain recognises that it has a political interest in the valorisation of Portugal's armed forces, in the reconstitution of its Navy and in the organisation and rearming of its Army, Portugal cannot play down its own importance, and play Britain's underdog:

Como nós, ela pretenderá amizade sincera, aliança fiel, colaboração necessária em termos de úteis, não um trambolho incómodo a confessar-se pelo mundo incapaz de lutar ou viver. (...) [Britain] wants, as much as we do, sincere friendship, a faithful alliance, necessary collaboration on useful terms, and not some sort of irksome stumbling block that goes around confessing to the world her inability to fight or live. (Salazar, 2016: 307) 
Or, to put it differently, although the Anglo-Portuguese Alliance is highly valued, Portugal cannot afford to be dependent on Britain's good will. Quite the contrary: it must show its ability to define its own course of action and prove it, and oppose, if necessary, those who, in Britain, unable as they are to perceive the true nature of the Spanish conflict and of the risks that haunt the Iberian Peninsula, rush to judge the Portuguese Government. That is the reason why Salazar dismisses the importance of those criticisms, which he benignly sees as evidence of the frankness that exists between the two countries - a frankness that only helps to consolidate the Alliance and that should not be confused with disloyalty.

He concludes by stating: "the Alliance is not our whole foreign policy and it is not up to England to defend, before or even against us, all our interests". On the other hand, he feels compelled to clarify that, in relation to the Spanish case, unlike what some people say, Portugal is not against the British policy on this question, but at the same time the two countries do not necessarily have to be on the same page. Britain may see the non-intervention policy as way to allow the Spaniards to settle their own affairs internally, without external influence. For Portugal, this is much more than just a matter of principle or conviction. It is rather born out of necessity, and it is here, and in the methods to accomplish this purpose, where the paths of both countries sometimes diverge.

The public opinion in Britain and France not only fails to understand the grave risks that Portugal is facing, but is misinformed about the "true Spanish problem and the nature of the events that unfold there". (Salazar, 2016: 308) People elsewhere may play down the communist threat, but in Portugal "we see it and feel it" and if communism gains a foothold in Spain, the Spanish people will no longer be able to decide their own future and choose their own regime. Salazar's twisted argument is grounded on the idea that nationalism and self-determination are two sides of the same coin. Nations are threatened by the intervention of the (Communist and Socialist) Internationals, which impose their own agendas on the will of the peoples - failing to mention, of course, the violence inflicted by nations upon other nations (as is also the case of colonialism).

It is at this point of the speech that Salazar makes the case for Spanish nationalism: non-intervention cannot play against Franco's 
forces, as they are the one true effective barrier against the advance of what he calls "Iberian communism". (308) Hence, the hatred borne to Salazar and his regime - a feeling he does not fear and believes to be fully justified. His argument comes full circle: as stated in the beginning of the speech, his intention was to unearth the causes of the attempt on his life. There was, however, another equally important intention, which was to signal Britain that the Portuguese regime came out stronger from the events of 4 July and that His Majesty's Government could go on relying on the Portuguese to keep their part of the bargain. Despite the criticisms voiced in the international press, the Anglo-Portuguese Alliance was to remain the focal point of the bilateral relations of both countries. And he rounds off his address with a positive note on Portugal's willingness to collaborate with Britain by making reference to the gratitude that the British Government expressed for the invitation to appoint observers to follow the inspection of the Portuguese-Spanish border. This is not to be seen as a concession to Britain, but as a commitment to the transparency that should govern the relations between both countries. The last word in his speech, an explicit reply to the perpetrators of the attempt, sounds ominous: "continuamos" [which could be translated into "we endure" or "persist"].

This aura of invincibility and missionary zeal had been captured by Fox when he visited the country back in 1936 before he joined the International Brigades. His views would differ significantly from those of his fellow-countrymen of the National Government. The words he uses are virtually the same used by Salazar, but with a heavy dose of irony:

Nothing if not up-to-date, Portugal has its national saviour. This gentleman, like his colleagues Franco, Mussolini and Hitler, is also ambitious to save civilization and understands clearly that the shortest, and therefore most merciful, road to salvation of civilization is through its destruction. (...) Dr Salazar has been more fortunate than his fellow-dictators in that he has had an almost universally good press in other countries. The Times considers him "one of the greatest finance ministers of modern times" and Dr Salazar himself is understood to consider this rather an understatement". (Fox, 1937: 45) 


\section{Conclusion}

Reading Salazar's notes and speeches substantiates Fox's assessment. The Portuguese dictator was aware of the nature of the difficulties the regime was facing with a country steep in a fratricide war just across the border. Salazar did not believe in the virtues of democracy. The social and political instability that characterised the First Republic in Portugal and the Second Republic in Spain had given him enough reasons to question the viability and sustainability of democratic regimes in the Iberian Peninsula. Franco, on the contrary, embodied the adamant spirit of the Spanish people trying to fight off the hordes of communists bent on the destruction of civilization (that is, Salazar's very special brand of "civilization") and the abandonment of the traditional values upon which rests the identity of the nations. ${ }^{11}$ On the other hand, Salazar also knew how far he could go in his steering of the regime's relations with the British Government. In military and economic terms, Britain had the upper hand, but Portugal's strategic location, which had allowed the Anglo-Portuguese Alliance to survive for so many centuries, was key to Britain's hegemonic aspirations. Sacrificing that in favour of an unstable democracy tainted by left idealism would not certainly be in Albion's best interest. As his address at the National Assembly shows, Salazar felt it important to remind the British Ally of the relation of mutual dependency that existed between the two nations.

\section{Works Cited}

Bourne, Kenneth. The Foreign Policy of Victorian England, 1850-1902. Oxford: The Clarendon Press, 1970.

Fox, Ralph. Portugal Now. London: Lawrence and Wishart, 1937.

Garcia, José Luís Lima. Ideologia e Propaganda Colonial no Estado Novo. Doctoral Thesis. Coimbra: Universidade de Coimbra, 2011.

11. Franco, too, thought highly of Salazar. In an interview for Le Figaro on 13 January 1958, he claimed: "the most accomplished, respectable statesman, of all he had known, I will tell you, it is Salazar. Here you have an extraordinary character, for his intelligence, his political sense, his humanity. His only defect is maybe his modesty." (Apud Preston,1998: 61) (My translation). 


\section{REAP/JAPS 26}

Kuin, Simon. "A Mocidade Portuguesa nos Anos 30: Anteprojectos e Instauração de uma Organização Paramilitar da Juventude". Análise Social, 28 (122), 1993: 555-588.

Nogueira, Franco. Salazar, III: As Grandes Crises (1936-1945). Porto: Civilização, 1983.

Oliveira, César de. Salazar e a Guerra Civil de Espanha. Lisboa: O Jornal, 1987.

Preston, Paul. Las Tres Españas del 36. Barcelona: Plaza \& Janés, 1998.

Queirós, António de Eça de. "Propaganda e Cultura Colonial". Jornal do Comércio e das Colónias, 9 October 1933.

Salazar, António Oliveira. Discursos e Notas Políticas 1928 a 1966. Obra Completa. Coimbra: Coimbra Editora, 2016.

---. Discursos e Notas Políticas II - 1935 a 1937. Coimbra: Coimbra Editora, 1937.

Stone, Glynn A. The Oldest Ally: Britain and the Portuguese Connection, 19261941. Woodbridge: Boydell Press, 1994.

---. "Britain, Non-Intervention and the Spanish Civil War". European Studies Review, No. 9 (1979): 139-145.

---. "The Official British Attitude to the Anglo-Portuguese Alliance, 19101945". Journal of Contemporary History, No. 10 (1975): 729-746.

Thomas, Hugh. The Spanish Civil War. London: Eyre \& Spottiswoode, 1961.

Torgal, Luís Reis. Estados Novos, Estado Novo: Ensaios de História Política e Cultural. Vol. I. Coimbra: Imprensa da Universidade de Coimbra, 2009a.

---. "Salazar and the Portuguese 'New State' - Images and Interpretations". Annual of Social History, 2 (2009b): 7-18. 